\title{
CO-MOVEMENTS OF REIT INDICES WITH STRUCTURAL CHANGES BEFORE AND DURING THE SUBPRIME MORTGAGE CRISIS: EVIDENCE FROM EURO-MED MARKETS
}

\author{
Pinar EVRIM MANDACI ${ }^{a}$, Bora AKTAN ${ }^{b, *}$, Efe Çaglar CAGLI ${ }^{a}$ \\ ${ }^{a}$ Dokuz Eylul University, Faculty of Business, Accounting and Finance Department, Kaynaklar \\ Campus, Buca, Izmir, Turkey \\ ${ }^{b}$ University of Bahrain, College of Business Administration, Department of Economics and Finance, \\ Isa Town, Kingdom of Bahrain
}

Received 12 February 2012; accepted 15 August 2012

\begin{abstract}
This paper examines the long-run relationships between the REIT indices of the UK, Turkey and Israel in the Euro-Med zone with that of MSCI US REIT Index by using weekly data over the period 2003Q3 through 2009Q3, which includes the latest US subprime mortgage crisis and its effects on global stock markets. Although our EG test results do not indicate a long-run relationship, after taking account of the structural changes by applying the GH test, we find a long-run interaction between the REIT indices of UK and Israel with that of the US. However, our results indicate the lack of co-movement between REIT index of Turkey with the US. In addition, our dynamic OLS test results indicate a perfect relationship between the UK and the US indices. Our findings show that international investors who make long-term investments can only gain from diversifying into the real estate market of Turkey among the involved markets in the Euro-Med zone.
\end{abstract}

KEYWORDS: Co-movements; REIT; EuroMed; US; Crisis

REFERENCE to this paper should be made as follows: Evrim Mandaci, P.; Aktan, B.; Cagli, E. C. 2014. Co-movements of REIT indices with structural changes before and during the subprime mortgage crisis: evidence from Euro-Med markets, International Journal of Strategic Property Management 18(1): 1-10.

\section{INTRODUCTION}

In the wake of a long boom period in the last decade for both commercial and residential real estate markets particularly in developed countries, we have witnessed the worst financial crises in history that began in the US and then spread to Europe, Asia and the rest of the world since the Great Depression (Masood et al. 2010; Aktan, Icoz 2009). While this bull market nowadays appears to have ended, not only many researchers but also many practitioners believe that the addition of real estate to the financial asset investments provide significant gains in portfolio performance (Aktan, Ozturk 2009). Alternatively, REITs (Real Estate Investment Trusts) which can be defined as closed-end investment companies managing portfolios composed of real estates, real estate based projects and

\footnotetext{
* Corresponding author. E-mail: boraktan@gmail.com
}

capital market instruments based on real estates and offer an option to direct-asset investment for investors, are increasingly becoming an important part of investors' diversified portfolios.

Most of the previous studies those analyzed comovements of the equity markets initially focused on the relationship between developed markets. However, after the 1980s with the deregulation and liberalization of the developing countries, finance researchers have begun to examine the relationship between the developed and emerging markets. Most of these studies argue that portfolios including emerging markets provide more diversification opportunities for investors. However, some of the studies conclude that world equity markets has become increasingly integrated. Thus, there are decreasing opportunities for international portfolio diversification. If decreasing 
opportunities of diversification in equity markets is the case, it is essential to be interested in other financial instruments in world markets. Hence, in this paper, long-run linkages between the international REIT indices are analyzed. We examine the relationship among some of Euro-Med countries Turkey, Israel, and the UK with the US over the period 2003Q3 through 2009Q3 which includes the latest US sub-prime mortgage crisis and its effects on global stock markets.

The paper has three important contributions to the finance literature. First, the benefits of global allocation and international diversification have been well documented in finance literature. There have been a plethora of studies that examine the short-term or long-term integration between international stock markets. However, there are only a few studies examining long-term relationship between international real estate markets. This paper tries to fill this gap and aims to examine the potential diversification opportunities that may arise by investing into international real estate securities. Second, most of the previous studies on the integration of the real estate markets are for the developed countries. There are a few studies dealing with emerging markets. We choose two important emerging real estate markets among the Middle East countries in the Euro-Med zone and investigate the co-movements of these markets with the US, which is the leading market in the world. Third, most of the present studies have tended to test unit root and co-integration without considering structural changes. However, in this paper, besides the conventional unit root tests; Augmented Dickey and Fuller (ADF) (1979) and Philips and Perron (PP) (1988), we apply Zivot and Andrews (ZA) (1992) and Lumsdaine and Papell (1997) unit root tests and Gregory and Hansen (GH) (1996) co-integration test which consider the structural changes in the data and provide more reliable results. Considering structural breaks in the analyzed period is primarily important due to beginning of sub-prime mortgage crisis in 2007, which seems to a cause a structural break in REIT indices data. In addition, we employ the Engle and Granger (EG) (1987) co-integration test as a benchmark, which does not allow for structural breaks.

The paper is organized as follows: following the introduction, in second section, previous studies are presented, in third section; data and methodology of the study are given. In fourth and fifth sections, we present the empirical results and the conclusion respectively.

\section{PREVIOUS STUDIES}

Among the earlier studies, Ziobrowski and Curcio (1991) argued that the US real estate market did not offer diversification benefits to UK and Japanese investors, in contrast Asabere et al. (1991) found that returns on international property stocks were negatively correlated with US T-bills and low correlated with the US securitized property market which provided evidence that real estate securities improved portfolio efficiency for the U.S. investors. They also found that international real estate securities had a higher risk and return relative to the US REITs. Eichholtz (1996) tried to investigate the effectiveness of international real estate diversification relative to international diversification of stock and bond portfolios. He tested the correlation structures between the international stock returns, international bond returns and international real estate stock returns and found significantly lower correlations between national real estate returns than between common stock or bond returns. His findings indicated the international investment in real estate securities provided more diversification benefits than the corresponding benefits from common stock and bond portfolios. Liu and Mei (1998) examined whether the monthly returns on stock and real estate related securities are predictable in six countries (Australia, France, Japan, S. Africa, UK and US) over the 1980-1991 period and found that the predicted portion of the returns on both stocks and real estate securities was small. They concluded that investing in international real estate related securities provided additional diversification benefits over and above those associated with international stocks markets.

In their paper, Eichholtz et al. (1998) examined the influence of continental factors upon international real estate returns and found strong continental factors in North America and Europe. For the Asia-Pacific region, real estate returns were not driven by a continental factor. These results suggested that for European, North American and Asia-Pacific investors, the Asia-Pacific region provides an attractive international diversification opportunity. Goetzmann et al. (1999) found relatively high correlations among international real estate markets during the period 1987-1997. Ling and Naranjo (1999) used traditional asset pricing models to test whether commercial real estate markets in the U.S. were integrated with stock markets. They found that the exchange-based real estate markets were integrated with exchange-based stock markets. In their study, Ziering et al. (1999) 
indicated that the correlation between REITs and the broader equity market had begun to decline in 1991.

Gordon et al. (1998) examined international real estate securities within the framework of a mixed-asset portfolio consisting of US stocks, US corporate bonds, US real estate securities, and international common stocks. Each asset class was examined from a risk-return perspective and the results indicated that international real estate securities offered significant diversification benefits for a US investor. Similar to the study of Gordon et al. (1998), Conover et al. (1999) found lower correlation between US and international real estate returns than foreign stock market returns.

Barry and Rodriquez (2004) evaluated diversification possibilities by using the property indices of fifteen emerging markets and twenty-one developed markets. They compared and analyzed the correlation returns and risk adjusted performance of each of the property indices and found that the real estate investments offered diversification opportunities to equity market investors in emerging markets as well as to real estate and equity market investors in developed markets.

Stated studies used simple correlation techniques to investigate the relationship between international security markets. Most of these studies argued that the inclusion of REITs in a general portfolio provides good opportunity for diversification. However, simple correlation analysis looks only at linear relationships and potentially ignores the long-run economic effects. There are a few studies using cointegration analysis to examine the long-run linkages between real estate and other capital markets or among real estate indices.

Myer et al. (1997) examined the stochastic properties of the real estate wealth for the US, Canada and UK and for several property types. They applied the Johansen's cointegration test and found the evidence of cointegration among the real estate indices across these three countries and argued that the inflationary expectation was a common factor that created a link among the indices. Tarbert (1998) utilized from the Johansen (1988) cointegration procedure and used publicly traded indices to investigate diversification opportunities available to UK investors and found the evidence of cointegration among sectors and across regions which indicates the limited sectoral and geographical diversification benefits for property portfolios.

Glascock et al. (2000) examined the integration of REIT, bond and stock returns using coin- tegration and vector autoregressive (VAR) models. Their results showed that REITs behaved more like stocks and less like bonds after the structural changes in the early 1990s. Results suggest that the benefits of diversification by including REITs in multi asset portfolios diminished after 1992. Tuluca et al. (2000) found that the price indices of capital and real estate markets (T-bills, bonds, stocks, securitized real estate and direct real estate) were cointegrated. Liow (2000) found that Singapore commercial real estate market is cointegrated with property stock market and major macro-economic factors.

Garvey et al. (2001) examined the linkage between securitized property indices in Australia, Hong Kong, Japan and Singapore using co-integration and Granger causality techniques. They concluded that with the exception of Australia, each of the other markets showed an improvement in performance from extending their real estate portfolios into the remaining Asian markets. Kleiman et al. (2002) tested for market efficiency by using stock market indices of real estate share prices for the three regions: Europe, Asia, and North America and their findings supported for random walk behavior and weak-form market efficiency. In addition they applied Johansen-Juselius cointegration analysis (Johansen, Juselius 1990) and found that all three markets were cointegrated. The results of the vector error correction models for those models exhibiting cointegration largely confirmed the existence of a long-run relationship and the lack of a short-run relationship among these real estate markets. They argued that diversification benefits through international real estate securities can only be achieved in the short run. Wilson and Zurbruegg (2002) tested for co-integration among the markets of UK, USA, Australia and Japan by applying the Gregory and Hansen co-integration test and found that the real estate markets were cointegrated after the structural breaks are taken into account.

On the other hand, Payne and Sahu (2004) analyzed the random walk hypothesis for the US and world commercial real estate markets along with the world stock market and found that each of these markets exhibited random walk behavior. In addition, Johansen-Juselius co-integration tests revealed that the three markets were not co-integrated. The vector autoregressive model showed little or no predictive power in explaining the variation in monthly returns. They concluded that investors could achieve diversification benefits both in long run and short run. 
Liow and Yang (2005) analyzed whether securitized real estate and stock markets had longterm co-memories and implications for short-term adjustment and found evidence to support fractional cointegration between securitized real estate prices, stock market prices and key macroeconomic factors of the Asia-pacific economics and US. The implication was that securitized real estate and common stocks were substitutable assets over the long run and these assets may not be held together in a portfolio for diversification purpose.

Basse et al. (2009) investigated the relationship between REITs and utility stocks of the United States by considering structural breaks. They concluded that investing in U.S. REITs is risky because of the structural breaks due to the financial crisis.

Thus, in light of the presented overview of the literature, there have been no studies on emerging real estate markets testing for co-integration with structural breaks. This study attempts to fill this gap in the related literature.

\section{THE METHODOLOGY}

\section{Unit root tests}

First we employ ADF and PP unit root tests which do not allow for the structural breaks to examine the stationarity of the time series and determine the integration order of non-stationary time series. Since the time series that have the same integrated order can be co-integrated, we try to determine the order of integration of the REIT indices. The ADF test that was developed by Dickey and Fuller (1979) is based on the following equation:

$$
\Delta y_{t}=\alpha+\beta t+(\rho-1) y_{t-1}+\sum_{i=1}^{k-1} \theta \Delta y_{t-i}+u_{t},
$$

where: $\Delta=1-L, y_{t}$ is stock price at time period $t$; $t=$ trend variable, and $u_{t}$ have white noise with the null hypothesis of $H_{0}: \rho=1$. However, if $k$ increases to huge numbers, ADF test becomes weaker. In order to eliminate this problem, we apply the PP test proposed by Phillips and Perron (1988) that is based on the following equation:

$$
y_{t}=\alpha_{o}+\alpha y_{t-1}+v_{t} .
$$

In case of the existence of structural break in time series, unit root tests, such as $\mathrm{ADF}$ and PP, lose power and channel researchers to the unreliable conclusion of nonstationarity although the alternative hypothesis of stationarity is true. To eliminate this shortcoming, we use Zivot and An- drews (1992) unit root test, which allow for one structural break. We employed a version of ZA test which allows for a structural break in both the intercept and slope:

$$
\begin{aligned}
& \text { Model C: } \Delta y_{t}=\mu+\beta t+\alpha y_{t-1}+\theta D U_{t}+ \\
& \gamma D T_{t}+\sum_{i=1}^{k} \eta_{i} \Delta y_{t-i}+\varepsilon_{t}, \\
& D U_{t}= \begin{cases}1, & \text { if } t>T_{B}, \\
0, & \text { otherwise }\end{cases} \\
& D T_{t}= \begin{cases}t-T_{B}, \quad \text { if } \quad t>T_{B} . \\
0, & \text { otherwise }\end{cases}
\end{aligned}
$$

Structural break occurs at time point of $T_{B}$. $D U_{t}$ is capturing a shift in the intercept, and $D T_{t}$ represents a shift in the trend. Rejection of the null hypothesis of $\alpha=0$ means that time series are stationary.

Lumsdaine and Papell (1997) argued that if there are two structural breaks, unit root tests with one structural break will lead unreliable results. In other words, unit root test that account for two structural breaks is more powerful than those, which only accommodate for one structural break so that in this paper we go one step further and try to investigate two structural breaks. Lumsdaine and Papell (1997) introduced a new model as an extension of model $\mathrm{C}$ by including two endogenous breaks. Model CC can be represented as follows:

$$
\begin{aligned}
& \Delta y_{t}=\mu+\alpha y_{t-1}+\beta t+\theta_{1} D U 1_{t}+\theta_{2} D U 2_{t}+ \\
& \gamma_{1} D T 1_{t}+\gamma_{2} D T 2_{t}+\sum_{i=1}^{k} c_{i} \Delta y_{t-i}+\varepsilon_{t}, \\
& D U 1_{t}= \begin{cases}1, & \text { if } t>T_{B 1}, \\
0, & \text { otherwise }\end{cases} \\
& D U 2_{t}= \begin{cases}1, & \text { if } \quad t>T_{B 2}, \\
0, & \text { otherwise }\end{cases} \\
& D T 1_{t}= \begin{cases}1-T_{B 1}, \quad \text { if } \quad t>T_{B 1}, \\
0, & \text { otherwise }\end{cases} \\
& D T 2_{t}= \begin{cases}1-T_{B 2}, & \text { if } \quad t>T_{B 2}, \\
0, & \text { otherwise }\end{cases}
\end{aligned}
$$

where: two dummy variables of $D U 1_{t}$ and $D U 2_{t}$ are indicators for structural breaks in the intercept at $T_{B 1}$ and $T_{B 2}$, respectively. However, the other dummy variables of $D T 1_{t}$ and $D T 2_{t}$ are indicators for structural breaks in trend at $T_{B 1}$ and $T_{B 2}$, respectively. kmax is set to 12 in the test procedure. The "trimming region", in which I have searched 
for $T_{B 1}$ and $T_{B 2}$ cover the $0.15 \mathrm{~T}-0.85 \mathrm{~T}$ period. I have selected the break points $\left(T_{B 1}\right.$ and $\left.T_{B 2}\right)$ based on the minimum value of the $t$ statistic for a. Similar to ZA test, rejection of the null hypothesis of $\alpha=0$ means that time series are stationary.

\section{Co-integration tests}

Having found that each of the REIT indices has unit root, first we implement the two-step EngleGranger (1987) cointegration test ${ }^{1}$. In the first step, EG uses the following ordinary least squares (OLS) regression in testing the null hypothesis of no cointegration:

$$
y_{t}=\alpha+\beta x_{t}+u_{t},
$$

where: both $y_{t}$ (dependent) and $x_{t}$ (explanatory) variables are integrated of order one (I(1)). In the second step of estimation, an ADF-type unit root test is run on the regression residuals, $\hat{u}=y_{t}-\hat{\alpha}-\hat{\beta} x_{t}$ here $\hat{\alpha}$ and $\hat{\beta}$ re the estimates of $\alpha$ and $\beta$ If the estimated ADF test statistic is higher than critical values suggested by MacKinnon (1991), null of no cointegration will be rejected.

Then, we apply the Gregory and Hansen (1996) co-integration method bearing an unknown structural break, because of the assumption that cointegration vectors are time invariant. Since ADF and $\mathrm{PP}$ tests are not appropriate in the presence of structural breaks GH test gives better result when investigating co-integration. Standard model of cointegration with no structural break can be written as:

$$
y_{1 t}=m+\alpha^{T} y_{2 t}+e_{t} \quad t=1,2, \ldots, T .
$$

To determine structural change reflected in changes in the intercept $\mu$ and/or changes in the slope $\alpha$, the dummy variable $\varphi_{t \tau}$ is added to the model. In this way, three models are created:

Model 1: Level Shift (C)

$$
y_{1 t}=m_{1}+m_{2} \varphi_{t \mathrm{t}}+\alpha^{T} y_{2 t}+e_{t} \quad t=1,2, \ldots, n,
$$

where: the dummy variable $\varphi_{t \tau}=1$ if $t>[n \tau]$ and 0 otherwise, where the unknown parameter $\tau \in(0,1)$ denotes the (relative) timing of the change point, and [ ] denotes integer part. Level shift is the re-

1 In this paper, it might be possible to employ other cointegration tests such as Johansen (1988) that is multivariate generalization of Dickey-Fuller test. However, it is more appropriate to employ Engle and Granger (1987) two step procedures since it is an underlying methodology of Gregory and Hansen (1996) co-integration test that we additively use in this paper. In addition, it will be redundant to apply both Engle and Granger (1987) and Johansen (1988) together since their results are generally consistent with each other. sult of a change in the intercept $\mu$, due to structural change while the slope coefficient $\alpha$ is constant.

Model 2: Level Shift with Trend (C/T)

$$
\begin{aligned}
& y_{1 t}=\mu_{1}+\mu_{2} \varphi_{t \tau}+\beta t+\alpha^{T} y_{2 t}+e_{t}, \\
& t=1,2, \ldots, n .
\end{aligned}
$$

Level shift with model $(\mathrm{C} / \mathrm{T})$ is the one added time trend into the level shift model.

Model 3: Regime Shift (C/S)

$$
\begin{aligned}
& y_{1 t}=\mathrm{m}_{1}+\mathrm{m}_{2} \varphi_{t \mathrm{t}}+\alpha_{1}^{T} y_{2 t}+\alpha_{2}^{T} y_{2 t} \varphi_{t \mathrm{t}}+e_{t}, \\
& t=1,2, \ldots . ., T .
\end{aligned}
$$

where: $\mu_{1}$ and $\alpha_{1}$ denote the intercept and slope coefficients before the regime shift, and $\mu_{2}$ and $\alpha_{2}$ denote the changes to the intercept and slope coefficients at the time of the shift; $\varphi_{t \tau}$ is the dummy variable indicating the time of the regime shift, $\tau$.

After the residuals, $e_{t}$, obtained from models estimated by OLS are used for forming the Phillips's (1987) test statistics $Z_{\alpha}(\tau), Z_{t}(\tau)$ or the ADF statistic emphasizing the break point, the null hypothesis of no co-integration in the possible presence of breaks are tested by using the smallest values of these statistics.

Since time series generally has a unit root, standard errors of coefficients is estimated incorrect by conducting conventional OLS algorithm. Thus, it is more efficient to apply Fully Modified OLS (FM-OLS) (Phillips, Hansen 1990) or Dynamic OLS (DOLS) (Stock, Watson 1993) procedures which estimate $\alpha$ and $\beta$ (in Equation 5) with appropriate standard errors. Because DOLS performs better in small samples, this procedure is conducted in this paper. DOLS also checks whether $\beta$ is different from unity, in other words, DOLS tests whether cointegration relationship between $y_{t}$ and $x_{t}$ is perfect (strong).

\section{DATA AND THE EMPRICAL RESULTS}

The data were obtained from Is Investment Inc., consist of weekly REITs indices for Turkey, Israel and UK which are part of the Euro-Med countries and the US covering the period 2003Q3 through 2009Q3, which includes the latest US subprime mortgage crisis and its effects on global stock markets.

The results for $\mathrm{ADF}$ and $\mathrm{PP}$ tests with and without trend are reported in Table 1. From both $\mathrm{ADF}$ and PP tests, it is observed that for all series the null hypothesis of the existence of unit root 
cannot be rejected at level of series. In addition, for both the ADF and PP tests with and without trend, the null hypothesis of unit root is rejected at first difference of series mostly at 1\% level. All series are found as integrated of order one. In other words, conventional unit root tests indicate that time series have a unit root.

The results of ZA test are reported in Table 2 with the maximum lag length equal to 12 and with the t-test results in parentheses. We do not reject null hypothesis for all REIT indices indicating that the series are non-stationary and have a unit root. Moreover, REIT indices of Turkey and the US have a statistically significant structural break in slope. However, the break in both intercept and slope is significant for Israel and UK. ZA test results are quite consistent with the $\mathrm{ADF}$ and $\mathrm{PP}$ unit root tests.

The structural break in the US REIT index was the result of the most recent financial distress that began in mid-2007, caused by the development in the subprime mortgage markets in the US. The structural break in Turkey REIT index in 2005 might be boosted by the Turkey-EU negotiations. The structural break in Israel REIT index in year 2006 might be the results of the Capital Market Reform which was initiated in the previous year.

Table 3 reflects the results of LP test allowing for the two most important structural breaks. According to Table 3 the null hypothesis suggesting a unit root cannot be rejected for all REIT indices. In case of the US and the UK, the first and the second structural breaks occurred at $\mathrm{TB}_{1}$ and $\mathrm{TB}_{2}$ respectively have affected both the intercept and the slope. On the other hand, in case of Turkey and Israel $\theta_{2}, \gamma_{1}$ and $\gamma_{2}$ are significant but $\theta_{1}$ is not which is suggesting that the second structural break occurred at $\mathrm{TB}_{2}$ for this REIT index has affected both the intercept and slope but the first one exercised a significant change in slope only. Not surprisingly, the most important structural breaks in these indices were observed during the most recent sub-prime crisis.

Table 1. Unit root tests (without structural breaks): ADF, PP

\begin{tabular}{llllll}
\hline & & ADF & & PP & \\
\cline { 3 - 4 } \cline { 5 - 5 } Israel & $\eta_{\mu}$ & $-1.9474(9)$ & First difference & Level & First difference \\
& $\eta_{\tau}$ & $-1.8049(9)$ & $-3.8993^{*}(8)$ & $-1.3555(5)$ & $-19.2926^{*}(6)$ \\
\multirow{2}{*}{ Turkey } & $\eta_{\mu}$ & $-2.2727(5)$ & $-3.9698^{* *}(8)$ & $-1.0863(5)$ & $-19.3609^{*}(5)$ \\
& $\eta_{\tau}$ & $-2.1468(5)$ & $-6.1875^{*}(4)$ & $-2.1976(10)$ & $-15.5342^{*}(8)$ \\
US & $\eta_{\mu}$ & $-1.7493(0)$ & $-6.3020^{*}(4)$ & $-1.9679(9)$ & $-15.5959^{*}(8)$ \\
& $\eta_{\tau}$ & $-1.4779(0)$ & $-17.9299^{*}(0)$ & $-1.7861(4)$ & $-17.9372^{*}(4)$ \\
UK & $\eta_{\mu}$ & $-0.8928(0)$ & $-18.0093^{*}(0)$ & $-1.5049(3)$ & $-18.0090^{*}(2)$ \\
& $\eta_{\tau}$ & $-1.0786(0)$ & $-18.2902^{*}(0)$ & $-0.9453(6)$ & $-18.2971^{*}(6)$
\end{tabular}

Notes: $\eta_{\tau}$ and $\eta_{\mu}$ refer to the test statistics with and without trend, respectively. *, and ** denote rejection of null hypothesis at $1 \%$ and $5 \%$, respectively. Numbers in parenthesis are optimum lags determined according to the Akaike Information Criteria (AIC).

Table 2. Zivot Andrews (Model C)

\begin{tabular}{|c|c|c|c|c|c|}
\hline Countries & TB & $\alpha$ & $\theta$ & $\gamma$ & $k$ \\
\hline Israel & 14.07 .2006 & $\begin{array}{l}-0.0460 \\
(-3.4340)\end{array}$ & $\begin{array}{l}0.0310 * * \\
(2.0207)\end{array}$ & $\begin{array}{l}-0.0007^{*} \\
(-2.7963)\end{array}$ & 9 \\
\hline Turkey & 19.08.2005 & $\begin{array}{l}-0.0379 \\
(-3.4370)\end{array}$ & $\begin{array}{l}0.0141 \\
(1.3944)\end{array}$ & $\begin{array}{l}-0.0005^{* *} \\
(-2.1406)\end{array}$ & 4 \\
\hline US & 18.05 .2007 & $\begin{array}{l}-0.0879 \\
(-3.6399)\end{array}$ & $\begin{array}{l}-0.0029 \\
(-0.2582)\end{array}$ & $\begin{array}{l}-0.0011^{*} \\
(-3.0944)\end{array}$ & 3 \\
\hline UK & 08.09.2006 & $\begin{array}{l}-0.0849 \\
(-3.8450)\end{array}$ & $\begin{array}{l}0.0268^{* *} \\
(2.1559)\end{array}$ & $\begin{array}{l}-0.0013^{*} \\
(-3.8832)\end{array}$ & 12 \\
\hline
\end{tabular}

Notes: * **, *** denote statistical significance at the $1 \%, 5 \%, 10 \%$ level, respectively. The critical values for $t_{\alpha}$ is -5.57 , -5.08 , and -4.82 at 1\%, 5\%, 10\% level, respectively (Zivot, Andrews 1992). 
Table 3. LP test results (Model CC)

\begin{tabular}{|c|c|c|c|c|c|c|c|c|}
\hline Countries & $T B_{1}$ & $T B_{2}$ & $\alpha$ & $\theta_{1}$ & $\theta_{2}$ & $\gamma_{1}$ & $\gamma_{2}$ & $k$ \\
\hline Israel & 21.09.2007 & 24.10 .2008 & $\begin{array}{l}-0.1762 \\
(-5.7460)\end{array}$ & $\begin{array}{l}0.0071 \\
(0.4649)\end{array}$ & $\begin{array}{l}-0.1252^{*} \\
(-4.1109)\end{array}$ & $\begin{array}{l}-0.0050^{*} \\
(-6.0660)\end{array}$ & $\begin{array}{l}0.0081^{*} \\
(6.5269)\end{array}$ & 9 \\
\hline Turkey & 28.10 .2005 & 05.09.2008 & $\begin{array}{l}-0.0834 \\
(-5.4270)\end{array}$ & $\begin{array}{l}0.0133 \\
(1.3742)\end{array}$ & $\begin{array}{l}-0.0876^{*} \\
(-5.0006)\end{array}$ & $\begin{array}{l}-0.0010^{*} \\
(-4.4293)\end{array}$ & $\begin{array}{l}0.0022^{*} \\
(4.8539)\end{array}$ & 4 \\
\hline USA & 10.11.2006 & 31.10. 2008 & $\begin{array}{l}-0.1926 \\
(-4.1051)\end{array}$ & $\begin{array}{l}0.0298 * * \\
(2.2681)\end{array}$ & $\begin{array}{l}-0.1630 * \\
(-5.9444)\end{array}$ & $\begin{array}{l}-0.0017^{*} \\
(-4.6155)\end{array}$ & $\begin{array}{l}0.0037^{*} \\
(4.5626)\end{array}$ & 11 \\
\hline UK & 01.12 .2006 & 02.01.2009 & $\begin{array}{l}-0.2030 \\
(-4.6921)\end{array}$ & $\begin{array}{l}0.0399^{*} \\
(2.8969)\end{array}$ & $\begin{array}{l}-0.1258^{*} \\
(-5.8934)\end{array}$ & $\begin{array}{l}-0.0031^{*} \\
(-5.3133)\end{array}$ & $\begin{array}{l}0.0060^{*} \\
(7.3270)\end{array}$ & 12 \\
\hline
\end{tabular}

Notes: $* * *, * * *$ denote statistical significance at the $1 \%, 5 \%, 10 \%$ level, respectively. The critical values for $t_{\alpha}$ is -7.34 , -6.82 , and -6.49 at $1 \%, 5 \%, 10 \%$ level, respectively (Lumsdaine, Papell 1997).

Having found that each of the series is nonstationary, we implement both the EG and GH cointegration tests for our comparison purposes; the former does not allow for a structural break, however the latter does.

From Table 4, the null of no cointegration is not rejected for all indices. There is no cointegration relationship between the REIT indices of the countries in question with US REIT index.

Table 5 indicates the results of GH co-integration test (in Gregory Hansen Cointegration test, United States has been considered as the base country). According to Model $\mathrm{C}$ which contains a level shift; Model C/T which contains a level shift with trend and Model C/S which contains a regime shift, all the test statistics - ADF, $Z_{\alpha}^{*}$ and $Z_{t}^{*}$ - support the existence of a long run relationship between the REIT indices of the US and the UK. In contrast to the EG test results, we find a significant
Table 4. Engle and Granger test results

\begin{tabular}{lll}
\hline Country & ADF statistic & $k$ \\
\hline Israel & -2.4565 & 10 \\
Turkey & -2.5480 & 0 \\
UK & -0.9839 & 10 \\
\hline
\end{tabular}

Notes: the figure in parenthesis is the critical value at $5 \%$ level. $k$ stands for optimum number of lags.

long-run relationship between the REIT indices of UK and US after taking account of the structural breaks. In addition, in case of Israel, despite the null hypothesis is rejected at the $10 \%$ level for $Z_{t}^{*}$ by Model C/T which allows for the level shift with trend, for the same model ADF test statistics is not rejected at this level. This does raise important questions regarding the long-run relationship.

On the other hand, in case of Turkey, parallel to the findings of the EG test, we do not observe

Table 5. Gregory and Hansen co-integration test results

\begin{tabular}{|c|c|c|c|c|c|c|}
\hline & $\mathrm{ADF}$ & $\mathrm{TB}$ & $Z_{t}^{*}$ & TB & $Z_{\alpha}^{*}$ & TB \\
\hline \multicolumn{7}{|c|}{ Israel } \\
\hline $\mathrm{C}$ & $-3.5664371(2)$ & 15.02.2008 & -3.7507651 & 20.08.2004 & -26.888983 & 16.07 .2004 \\
\hline $\mathrm{C} / \mathrm{T}$ & $-4.5710771(2)$ & 09.05 .2008 & $-4.8387339 * * *$ & 21.03.2008 & -42.552120 & 21.03 .2008 \\
\hline $\mathrm{C} / \mathrm{S}$ & $-4.2467918(0)$ & 28.03.2008 & -4.1079303 & 16.05 .2008 & -32.343631 & 16.05 .2008 \\
\hline \multicolumn{7}{|c|}{ Turkey } \\
\hline $\mathrm{C}$ & $-2.8600880(0)$ & 26.05.2006 & -2.8130182 & 07.07.2006 & -14.588835 & 07.07 .2006 \\
\hline $\mathrm{C} / \mathrm{T}$ & $-3.6401973(0)$ & 09.06 .2006 & -3.5456376 & 16.06 .2006 & -23.931796 & 16.06 .2006 \\
\hline $\mathrm{C} / \mathrm{S}$ & $-3.6175872(0)$ & 31.03.2006 & -3.5580060 & 31.03.2006 & -24.822646 & 31.03 .2006 \\
\hline \multicolumn{7}{|l|}{ UK } \\
\hline $\mathrm{C}$ & $-5.3772360 *(8)$ & 30.11 .2007 & $-5.4922456^{*}$ & 24.08.2007 & $-54.162194^{*}$ & 24.08 .2007 \\
\hline $\mathrm{C} / \mathrm{T}$ & $-5.3221210 * *(8)$ & 30.11 .2007 & $-5.4968116^{*}$ & 24.08.2007 & $-54.164380^{* *}$ & 24.08 .2007 \\
\hline $\mathrm{C} / \mathrm{S}$ & $-5.4095325^{* *}(8)$ & 30.11 .2007 & $-5.4822855^{*}$ & 24.08 .2007 & $-54.233278^{* *}$ & 24.08 .2007 \\
\hline
\end{tabular}

Notes: $* * *, * *$ denote the presence of cointegration at significance level of $\% 1, \% 5$, and $10 \%$, respectively. Critical values are taken from Gregory and Hansen (1996), Table 1, p: 109. 
Table 6. Coefficient estimates: dynamic OLS [USA]

\begin{tabular}{llll}
\hline & $\alpha$ & $\beta$ & $\mathrm{H}_{0}: B=1$ (Prob.) \\
\hline Israel & $-4.3545^{*}(1.2007)$ & $1.5365^{*}(0.17949)$ & 0.001 \\
$\mathrm{UK}$ & $0.44037(2.2859)$ & $1.1400^{*}(0.34171)$ & 0.682 \\
\hline
\end{tabular}

Notes: the figure in parenthesis is the standard error of the coefficient. * denotes statistical significance at the $1 \%$ level.

a long-run relationship between the REIT indices of Turkey and the US after considering the structural breaks.

After we find a significant long-run co-integration between the REIT indices of UK and US and a suspicious long-run relationship between Israel and US, we employ the Dynamic OLS model.

According to Table 6, a perfect link between the REIT indices of UK and Israel with that of the US would imply that $\beta=1$. Test of this hypothesis suggest that we cannot reject the null hypothesis for the UK. As for the test results of Israel, $B$ is significantly different from one which indicates that even though Israel REIT index tend to move together with that of the US, the link is less than perfect. The Dynamic OLS test results supports the results of the GH co-integration test.

\section{CONCLUSION}

The aim of this study is to provide some empirical evidence on the long-run relationship among the REIT indices of some Euro-Med countries and the US over the period 2003Q3 to 2009Q3. We employ the conventional unit root tests; Augmented Dickey and Fuller (1979) and Phillips and Perron (1988) to investigate whether the time series data are non-stationary. In addition, we conduct Zivot and Andrews (1992) unit root test, which allow for one structural break and Lumsdaine and Papell (1997) unit root test, which allow for two structural breaks in the series. We use both the Engle and Granger (1987) and Gregory and Hansen (1996) co-integration tests. Although our EG test results do not indicate a long-run relationship, after taking account of the structural changes by applying the GH test, we find a long-run interaction between the REIT indices of UK and Israel with that of the US. This is not a surprising result because among the countries in this study, UK has the largest economic and financial relations with the US, which might cause a long-run linkage between these countries real estate markets.

The findings of the present paper suggest that the international investors and global portfolio managers who make long-term investments have limited diversification benefits by investing into the real estate markets of in the Euro-Med zone we examine excluding Turkey, which is found as not having a long-run co-integration with the US. These findings offer a possibility for future research.

\section{REFERENCES}

Aktan, B.; Ozturk, M. 2009. Empirical examination of REITs in Turkey: an emerging market perspective, Journal of Property Investment and Finance 27(4): 373-403. http://dx.doi. org/10.1108/14635780910972297

Aktan, B.; Icoz, O. 2009. Revisiting the successive financial crises and bank failures on the threshold of global hell: a qualitative review, Investment Management and Financial Innovations 6(1): 38-47.

Asabere, P. K.; Kleiman, R. T.; McGowan Jr, C. B. 1991. The risk-return attributes of international real estate equities, Journal of Real Estate Research 6(2): 143-152.

Barry, C. B.; Rodriguez, M. 2004. Risk and return characteristics of property indices in emerging markets, Emerging Markets Review 5(2): 131-159. http:// dx.doi.org/10.1016/j.ememar.2004.03.001

Basse, T.; Friedrich, M.; Bea, E. V. 2009. REITs and the financial crisis: empirical evidence from the U.S., International Journal of Business and Management 4(11): 3-10.

Dickey, D. A.; Fuller, W. A. 1979. Distribution of the estimators for auto-regressive time series with a unit root, Journal of American Statistical Association 74: 427-431. http://dx.doi.org/10.1080/01621459.1979.1 0482531

Eichholtz, P. M. A. 1996. Does international diversification work better for real estate than for stocks and bonds?, Financial Analyst Journal 52(1): 56-62. http://dx.doi.org/10.2469/faj.v52.n1.1967

Eichholtz, P. M. A.; Huisman, R.; Koedijk, K.; Schuin, L. 1998. Continental factors in international real estate returns, Real Estate Economics 26(3): 493-509. http://dx.doi.org/10.1111/1540-6229.00754

Engle, R. F.; Granger, C. W. J. 1987. Co-integration and error correction: representation, estimation, and testing, Econometrica 55(2): 251-276.

Garvey, R.; Santry, G.; Stevenson, S. 2001. The linkages between real estate securities in the Asia-Pacific, $P a$ cific Rim Property Research Journal 7(4): 240-258.

Glascock, J. L.; Lu, C.; So, R. W. 2000. Further evidence on the integration of REIT, bond, and stock returns, Journal of Real Estate Finance and Economics 20(2): 177-194. http://dx.doi.org/10.1023/A:1007877321475

Goetzmann, W.; Bradford, C.; Rouwenhurst, K. G. 1999. Global real estate markets: cycles and fundamentals, 
Working Papers. Yale School of Management's Financial Research Network, 1-23.

Gordon, J. N.; Canter, T. A.; Webb, J. R. 1998. The effect of international real estate securities on portfolio diversification, Journal of Real Estate Portfolio Management 4(2): 83-91.

Gregory, A. W.; Hansen, B. E. 1996. Residual-based tests for cointegration in models with regime shifts, Journal of Econometrics 70(1): 99-126. http://dx.doi. org/10.1016/0304-4076(69)41685-7

Johansen, S. 1988. Statistical analysis of cointegration vectors, Journal of Economic Dynamics and Control 12(2-3): 231-254. http://dx.doi.org/10.1016/01651889(88)90041-3

Johansen, S.; Juselius, K. 1990. Maximum likelihood estimation and inference on cointegration with applications to the demand for money, Oxford Bulletin of Economics and Statistics 52(2): 169-210. http:// dx.doi.org/10.1111/j.1468-0084.1990.mp52002003.x

Kleiman, R. T.; Payne, J. E.; Sahu, A. P. 2002. Random walks and market efficiency: evidence from international real estate markets, Journal of Real Estate Research 24(3): 279-298.

Ling, D. C.; Naranjo, A. 1999. The integration of commercial real estate markets and stock markets, Real Estate Economics 27(3): 483-515. http://dx.doi. org/10.1111/1540-6229.00781

Liow, K. H. 2000. The dynamics of the Singapore commercial property market, Journal of Property Research 17(4): 279-291. http://dx.doi. org/10.1080/09599910010001402

Liow, K. H.; Yang, H. 2005. Long-term co-memories and short-run adjustment: securitized real estate and stock, Journal of Real Estate Finance and Economics 31(3): 283-300. http://dx.doi.org/10.1007/s11146-0052790-6

Liu, C. H.; Mei, J. 1998. The predictability of international real estate markets, exchange rate risks and diversification consequences, Real Estate Economics 26(1): 3-39. http://dx.doi.org/10.1111/15406229.00736

Lumsdaine, R. L.; Papell, D. H. 1997. Multiple trend breaks and the unit root hypothesis, Review of Economics and Statistic 79: 212-218. http://dx.doi. org/10.1162/003465397556791
Masood, O.; Aktan, B.; Pariente, G. 2010. A discussion of financial regulations impact on subprime crisis: implications for financial markets, International Journal of Business 15(1): 51-69.

Myer, F. C. N.; Chaudhry, M. K.; Webb, J. R. 1997. Stationarity and co-integration in systems with three national real estate indices, Journal of Real Estate Research 13(3): 369-381.

Payne, J. E.; Sahu, A. P. 2004. Random walks, cointegration, and the transmission of shocks across global real estate and equity markets, Journal of Economics and Finance 28(2): 198-210. http://dx.doi. org/10.1007/BF02761611

Phillips, P. C. B. 1987. Time series regression with a unit root, Econometrica 55(2): 277-301.

Phillips, P. C. B.; Hansen, B. E. 1990. Statistical inference in instrumental variables regression with 1(1) processes, Review of Economic Studies 57: 99-125.

Phillips, P. C. B.; Perron, P. 1988. Testing for a unit root in time series regression, Biometrika 75(2): 335-346. http://dx.doi.org/10.1093/biomet/75.2.335

Stock, J. H.; Watson, M. W. 1993. A simple estimator of cointegrating vectors in higher order integrated systems, Econometrica 61(4): 783-820.

Tarbert, H. 1998. The long-run diversification benefits available from investing across geographical regions and property type: evidence from cointegration tests, Economic Modeling 15(1): 49-65. http://dx.doi. org/10.1016/S0264-9993(97)00011-4

Tuluca, S. A.; Myer, N. F. C.; Webb, J. R. 2000. Dynamics of private and public real estate markets, Journal of Real Estate Finance and Economics 21(3): 279296. http://dx.doi.org/10.1023/A:1012055920332

Wilson, P. J.; Zurbruegg, R. 2002. Structural breaks, diversification and international real estate markets some new evidence, Briefings in Real Estate Finance 1(4): 348-366. http://dx.doi.org/10.1002/bref.44

Ziering, B.; Liang, Y.; Mclntosh, W. 1999. REIT correlations with capital market indexes: separating signal from noise, Real Estate Finance 15(4): 61-67.

Ziobrowski, J. A.; Curcio, J. R. 1991. Diversification benefits of U.S. real estate to foreign investors, Journal of Real Estate Research 6(2): 119-142.

Zivot, E.; Andrews, D. W. K. 1992. Further evidence on the Great Crash, the oil-price shock, and the unitroot hypothesis, Journal of Business \& Economic Statistics 10(3): 251-270. 


\section{APPENDIX}

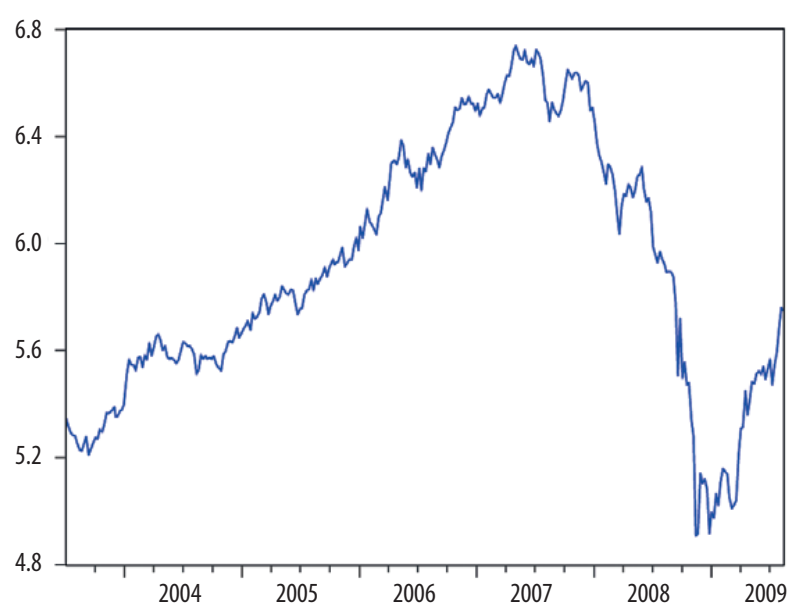

Fig. 1. Logarithmic price series of Israel

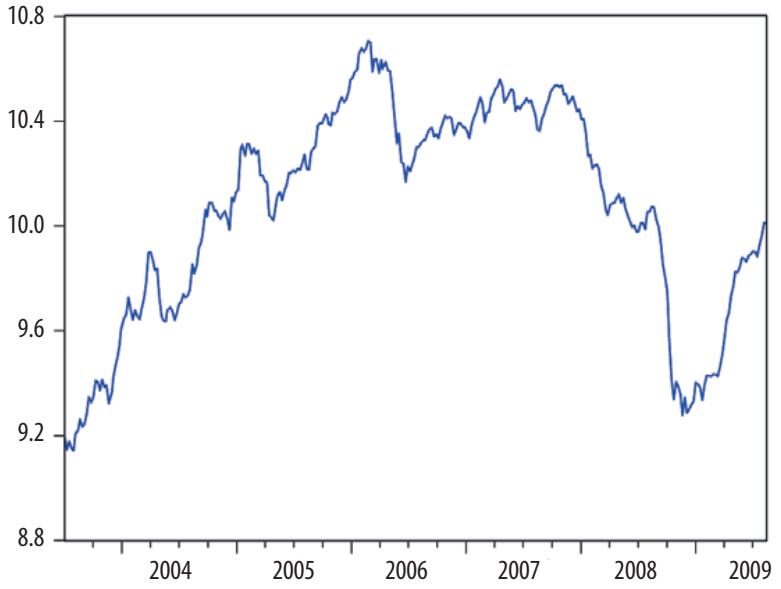

Fig. 2. Logarithmic price series of Turkey

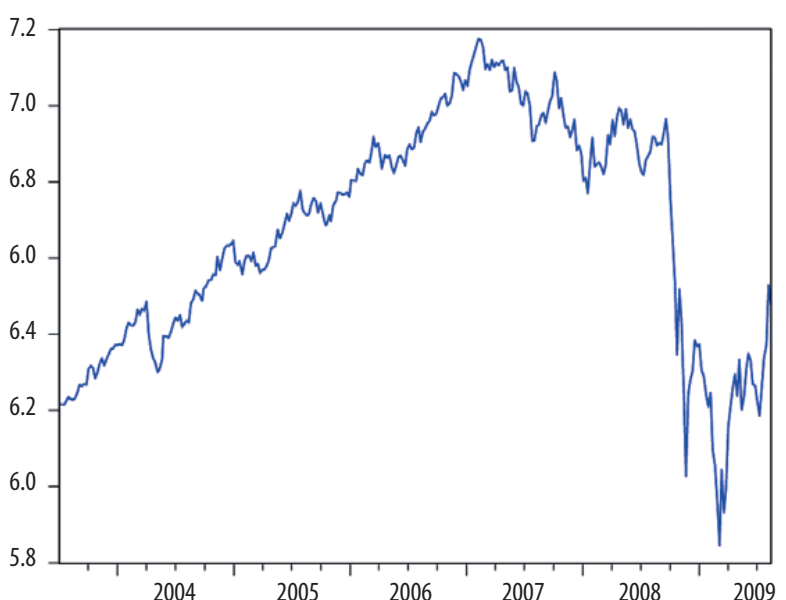

Fig. 3. Logarithmic price series of the UK

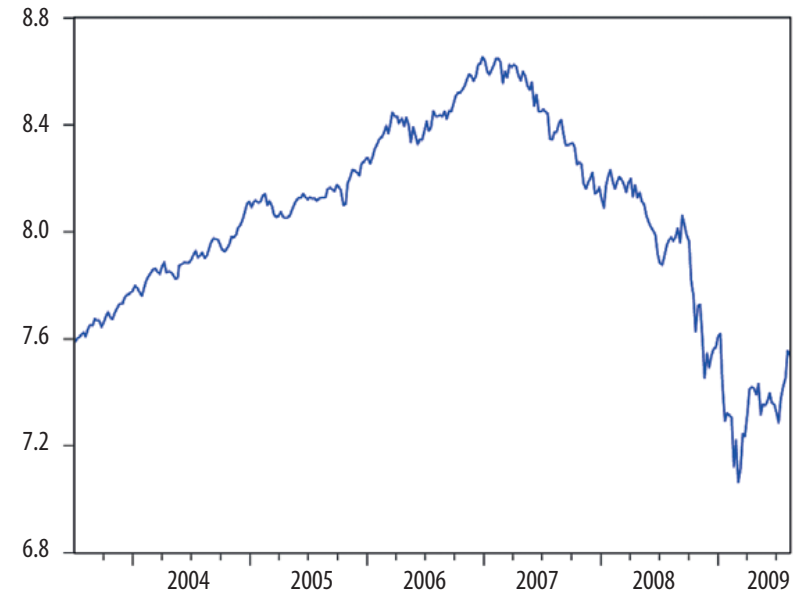

Fig. 4. Logarithmic price series of the US 